\title{
THE LIVING LIFE PROGRAM - STRATEGY FOR TRAINING OF COMMUNITY HEALTH AGENTS AS SOCIAL EDUCATORS TO GIVE COMMUNITY ATTENTION IN MENTAL HEALTH
}

\author{
O Programa Viva a Vida - estratégia de capacitação de agentes \\ comunitários de saúde como educadores sociais capazes de prestar \\ atenção comunitária em saúde mental \\ El Programa Viva la Vida - estrategia para entrenamiento de agentes \\ comunitarios de salud como educadores sociales capaces de prestar \\ atención comunitaria en salud mental
}

Cristina Loyola

Sebastião Rocha

\begin{abstract}
The Living Life Program which established in the state of Maranhão - Brazil 2001-2003, had three key areas: the excluded as clients, the training of the professionals involved as action strategy, and ethics which was orientated on the premise that every human being is born to be free, healthy, educated and happy as guidelines. Through the mental health training program, it was intended that the community health agents should gain the required knowledge to do three tasks: to identify suffering people mental problems, acknowledge this suffering in the patient's home and thirdly, to send the patient for specialist care in the region when necessary. This should be done to avoid non-therapeutic interventions, such as that often provided by the police. The comprehension that Program studies pertinent questions relating to mental health, is necessary to consider what human resources are required, so as to redirect the model for providing care, remembering that success can only be achieved in psychiatric care if at every point of care there is acceptance, treatment and social inclusion.
\end{abstract}

Keywords: Public Health. Mental Health. Primary Attention to Health.

\section{Resumo}

0 Programa Viva a Vida, desenvolvido no estado do Maranhão no período 2001-2003, trabalhou com três interfaces: com os excluídos como clientela, com o treinamento sofisticado dos profissionais envolvidos como estratégia de ação e com uma ética orientada pela premissa de que todo humano nasce para ser livre, saudável, educado e feliz como guia. Após o treinamento de dez mil agentes comunitários de saúde esperamos que eles sejam capazes de identificar pessoas em sofrimento psíquico, fazer 0 acolhimento deste indivíduo no próprio domicílio, em primeira instância, e quando não for possível, encaminhá-lo para atendimento especializado na região, evitando o envolvimento de instâncias não terapêuticas como a polícia . 0 entendimento que norteou o Programa foi o de que para estudar as questões pertinentes à saúde mental temos que definir que recursos humanos necessitamos para redirecionar o modelo assistencial. E reafirmar que para garantir o cuidado em saúde mental temos que ter acolhimento, tratamento e inclusão social.

Palavras-chave:

Saúde Pública. Saúde Mental. Atenção Primária à Saúde.

\section{Resumen}

El Programa Viva la Vida, desarrollado en el estado del Maranhão en lo período 2001 hasta 2003, ha trabajado con tres interfaces: con los excluidos como clientela, con el entrenamiento sofisticado de los profesionales envueltos como estrategia de acción y con una ética orientada por la premisa de que todo ser humano nace para ser libre, saludable, educado y feliz. Después del entrenamiento de diez mil agentes comunitarios de salud esperamos que ellos sean capaces de identificar personas en sufrimiento psíquico, acoger a este individuo en su domicilio, en primera instancia, y cuando no es posible, encaminarla a la atención especializada en la región, evitando el envolvimiento de instancias no-terapéuticas, como la policía. El entendimiento que norteó el Programa fué de que para estudiar las cuestiones pertinentes a la salud mental tenemos que definir qué recursos humanos necesitamos para alterar el modelo asistencial. Y recordar que para garantizar el cuidado en salud mental tenemos que tener acogimiento, tratamiento e inclusión social.

Palabras clave:

Salud Publica. Salud Mental. Atención Primaria a la Salud. 


\section{INTRODUCTION}

It is necessary to take acquaintance at certain key milestones in Brazil's Mental Health initiative: At the 1987 Mental Health Conference in Brazil, the approach was the take care based in publics and privates psychiatric hospitals described as expensive, incompetent, and violator of the basic human rights ${ }^{1}$. In 1989, Representative Paulo Delgado ${ }^{a}$ criticized the barriers that prevented changes in the government regulation about the care, highlighting the negative impact this was having on the actions of the more proactive cities and states. In 1992, the model of hospital care provision was changed so as to be founded upon citizen's rights. This was accompanied by reinforcement of the need to structure care provision around municipalities. And above all, local social control was seen as the strategic way forward. As result it was created the Center for Psychosocial Assistance (CAPS) and other points of clear treatment. Inspections, audits, and licensing of hospitals were introduced from the Center. However the core of the problem, which was the redirection of the model for care provision and a change in the lunatic asylum culture, which produced institutional rules, not as an optional activity but as the fundamental focus of all concerned. Thus, there were great challenges to be addressed: How do not produce more mental illness? How to protect individuals from institutionalized madness, the kind of institutional disease that kills slowly the human being undergoing rigid roles of health professionals and hard system of health?

In front of professionals there is the daily reality of psychiatric hospitals in Brazil, so different from that aimed for. How to change long established practices in hospitals, and exhausting institutional regulations? To attempt to change psychiatric hospitals demands such a large investment that it almost outweighs the benefits. There are emotional, financial and human costs to transform poor personal relationships into professional ones. Changes need relationships that are based on the needs of the individual, that are ethical and which focus on the patient's well-being. Is it possible to create professionals different to those currently found in hospitals, professionals who actually care? In 1995 ten proposals ${ }^{2}$ were written for the new millennium. The authors would highlight the first and last of these.

The first was to "Develop backwards", that was to bring ever larger masses of the under developed population to the first stages of progress; and the last was to "reduce the distance, which grows each day, between those who know a lot and those who know a little". There seems to be agreement about what is essential, but maybe we disagree strongly on the details, which is where issues really get resolved. In order to debate mental health, culture and society have to be examined, and people's quality of life expectations are to be faced. Aspirations of each and every one should be understood. In addition, some knowledge of the past trends and problems can help the management of the future.

\section{THE LIVING LIFE PROGRAM AND THE FAMILY HEALTH PROGRAM}

Talking about Maranhão State implies thinking of rhythms, sounds, colors, festivals, theater and dances that pulsates across diverse regions within a State. The diverse traditions reflect the ethnic mix of Maranhão - Native Brazilian, African, and Portuguese. The program LIVING LIFE (Viva a Vida) ${ }^{3}$, which is now discussed, is all about living together. Living together is the philosophy behind the program LIVING LIFE (Viva a Vida), an interstate and interinstitutional agreement signed in April of 2001, between the State Government of Maranhão and the Psychiatry Institute of Federal University of Rio de Janeiro. The utopian objective for this century is to give voice, power, dignity, and citizenship to these individuals. The program's target was population with mental ill, leprosy sufferers, and those excluded from school - all diverse groups considered of as having high social fragility.

It is an alliance of work, which requires a range of services and resources. Moreover, the more diverse and undefined the suffering is, the more diverse and undefined is the technology to be used. The technology may be diverse, but the objective must be clear; the principal humanistic idea of this project is that a person has the right to receive interventions based on his/her abilities and not on his/her difficulties. Another idea behind the LIVING LIFE (Viva a Vida) project is to instruct as much as possible those involved in health care. The Family Health Program (PSF) is a critical factor in forming what will be the Brazil's Mental Health Care System in the near future. It is considered by those that run the Unified Health System (SUS) as the strategy for reorganizing primary care in the country, and of the whole care model. The PSF should be seen in Brazil as bringing the ideal of "health for all" 4 . The program aims to gradually deliver technical competence, structure, and direction to primary health care. Therefore a possible vision of health care in Brazil must consider the diverse strands of strategy in service organization centered on the family health. It is a health care system that is trying to project a bridge between tradition and progress ${ }^{3}$. It notes that the process of modernization must accept the need for continuity between the wisdom of tradition and the boldness of the new. This program works on the social inclusion and citizen building of three important groups; those suffering from leprosy, the mentally ill, and those excluded from schools. The reason they can be seen as one group, is not their pains, a micro bacteria, or unfair educational policies. They are united by their daily experience of social exclusion, and by the pain of living with prejudice. These groups represent one side of the work, and demand a highly qualified professional team. It is a reference to those professionals that make up the teams of the Family Health Program, and with large numbers of Community Health Agents. Community Health Agents today count more than one hundred forty thousand (140.000) participants, taking care of around 82 million people in four thousand five hundred (4.500) municipalities. They represent the main drive of health care in Brazil.

At this moment, it's important to comment that throughout the last 10 years, the program has operated in so distant 
places that not everyone wants to visit, and few would want to live. It overcame the initial criticism of "poor medicine for the poor". However the implementation of Community Health Agents (ASC) was not to replace the health professionals with a cheap and unqualified workforce. Their entry into local health services, is due to the gaps left by the professionals who didn't value the presence of the community in their own locations and as co-responsible of professionals and communities. This desire to work with professionals with different background and training, more human in their method of caring for people, has caused difficulties at teaching institutions, both at higher level. The reasons for this were the urgent need to overcome the way in which professional training of health professionals in Brazil was undertaken. Problems emerged because of the disassociation between the teaching of sciences (Anatomy, Physiology, Histology, and other) in the first years and the clinical disciplines taught later in the professional cycle. There was too much focus on the individual, to the detriment of the community, on cure rather than prevention, on working under stable situations rather the more common disorder. The reality facing health services is one where policies are not integrated, leading to low success rates, with uncoordinated, centralized and above all fragile and non-existent social control.

The learning process of the Community Health Agents (ASC) shouldn't just result in acquiring basic health care skills and that is widely known. It must also involve the understanding of man in his social context, as a means to tackling the health/ illness process and its determinants. In this way, the Community Health Agent (ASC) is a promoter of health by excellence, a permanent educator in defense of life. It is important not to create false separations along the processes of birth, life and death. Community's participation in public policy as a strategy to improve quality of life should be encouraged. As well as the mission to improve the capacity of the community to look after its health and strengthen the integration between the community and the local health services, the biggest role of the Community Health Agent (ASC) is to have the ability to read, listen and translate population needs to public authorities. This must be done for each person, family, and community. When the Community Health Agent Program (PASC/1991) was designed, it was agreed that a Community Health Agent (ASC) should be someone who is totally identified with his/her own community. They should have the same values, customs and language. And their leadership abilities should reflect in improving health conditions for the community, helped by government action. The activities of the Community Health Agent (ASC) need to have, as basic support, a process of selfeducation. This process needs to be practical and should unify the community. It should lead to individuals and community groups engaging in the identification of their problems and needs.

At the same time, the activities should direct make possible resources to respond to the identified needs, understanding their problems, valuing their potential. This is all done in the hope that communities will develop themselves in an integrated and sustainable manner. Teamwork and co-operation, form the pathway to community education/action and one should not forget that community education is a community task. On the other hand, a community is not an abstract entity, but it exists within a concrete reality, with its own knowledge, and can itself recognize the potential of partnerships. This means getting to know the families and communities, not as a place with people to be supervised, but as an educational process - learning through teaching. The idea is to secure the whole team's participation in the collective work process; to value professionals at all levels; to respect the characteristics and limits of each person; to discuss and resolve problems in an active and integrated manner; to demystify the absolute power of those in charge. Above all, the program seeks to recover the dignity of the local health services and to gain the respect of the population. These were extremely important premises for working out the methods of the local health professionals in these towns.

The community education was done with the active participation of the Community Health Agents (ASC) and the nurses - the instructors and supervisors of PASC (Program of Community Health Agents). The Program LIVING LIFE (Viva a Vida) established in the state of Maranhão, Brazil since 2001, worked in three areas: the excluded, the training of involved professionals, and ethics. This was orientated on the premise that every human being is born to be free, healthy, educated and happy ${ }^{5}$. Many times using its own methods, the Program have constructed and deconstructed views and truths about mental health care. It was fundamental to establish a certain difference in relation to other processes which also seek to develop proposals, and the consequent definition of indicators of quality, but which arise from different values and perspectives and therefore come to conclusions very different to those taken as guidelines for the Living Life Program.

Some values appeared, explicitly or implicitly, in the health proposal in which we believed in, and we can group them didactically into ethical values (happiness, health, hope, selfesteem, brotherhood, faithfulness, politeness, loyalty, tolerance, and justice), political values (autonomy, persistence, knowledge, and greed), and esthetic values (sensitivity, creativity, beauty, harmony, and simplicity). They express a social project that recognizes the centrality of the individual whose needs and rights are the focus of this program. The State of Maranhão has approximately ten thousand (10.000) Community Health Agents (ASC) who undertake a very important public role. These agents, who strictly reside in the community in which they work, identify and record the population in their area, prioritizing needs and requirements, carrying out activities for the promotion of health for the individual and the community, encouraging society's participation in public policies aimed at improving people's quality of life.

With a precious knowledge of local culture, the daily work of the Community Health Agents (ASC) is structured around regular home visits to monitor the health of families. It is from the health-illness continuum of the subject, within his culture and community, that the Community Health Agents can propose 
health actions for both emergency and chronic cases. This work shows the difference, and the advantage, of out patient consulting. During the 24 months of this work, we have been able to count on the excellence of the Popular Center of Culture and Development (CPCD), a non-governmental organization and our partner in this project, in the stimulating and difficult task of training people, a challenge even greater when one is trying to instruct educators. We have trained more than eight thousand (8000) members of the teams from the Family Health Program as social educators, emphasizing the training of the health educators as proactive creators of opportunities, protagonists, and not as masters of knowledge. We are focusing our efforts on the health/education interface, the best way to impact primary health care.

Our Community Health Agents have to be, above all else, educators. The general objective is that they create a position as social educators of children, teenagers and adults, and act as agents for the development of health in the community, contributing to turn each municipality into a community of permanent learning. This implies the breaking and changing of old conceptions, beliefs, and a discussion of a new social role from the perspective of integrated health for individuals and the community. We must also reduce the loss of experts from Family Health Program (PSF), improve work satisfaction, and the diligence of the experts, and create meetings with proactive suggestions. The proposal is to add to the dialogue a mediator between the participants, to value and respect the individual differences, knowledge and actions of each. There needs to be a collective search for educational solutions for all the issues being experienced by the participants. In this way it is possible to secure the involvement, the participation and project ownership by the target communities; the training and creation of educators at the front line, committed to the construction of new knowledge and new methods of collective health. In summary, what one gains is community participation, not as the objective, but as an educational health process, enabling the program to take root and consolidate itself. Once created, the ASC receive training in mental health in their own municipalities, in tandem with the opening of Psychosocial Care Centers (CAPS) in the regions. While training ten thousand (10000) of Community Health Agents (ASC) as mental health care givers, it became clear that these simple municipalities can be considered rural environments.

For better or worse, the simple and generous ordinary inhabitants are distant from what psychiatry has created and produced in its model of hospital internship. A different solution is needed in this situation. Not exactly new asylum, but a fur ther work on community support to deal with mental disease outside the hospital. Community Health Agents had to be trained to act as support for simple care issues. Home visit is able to deal with $60 \%$ of mental health problems ${ }^{1}$. The less complex social net organization is, such as a rural environment, the more empowered community health agent is. Moderate depression, some neurosis type, although allow social functioning need health mental care.

\section{CONCLUSION}

So what is needed in Maranhão? Two kinds of problems require two different strategies. The so-called "lunatics asylums" are really terrible and exist, at least, three of them there. To try and reorganize them demands a cost that almost overweighs the benefits. Emotional costs, enormous financial and human resources caused by poor relationships which do not deliver the best for the patient. To avoid this, new psychiatric hospitals ${ }^{6}$ must learn with this program. They take too much of our time and it's no longer possible to wait another decade before change something at their lives. About inpatients, doesn't seem to have any doubt to me. A census and analysis of the profile of inpatients must be done. It is urgent to establish what is necessary to help the patients face the challenge of life (for example, what is citizenship without the knowledge of read and write?). In relation to the primary health care, the staff of the Family Health Program (PSF) should carry it out, about one thousand (10.000) Community Health Agents (CHA), that are in Maranhão, must be available now.

Through the mental health training, the expectation of the Community Health Agents is to get knowledge to do three things: Remember that they are dealing with primary care, where the ASC look after about 100 families and visit the houses of these families, attended to: firstly, identify people that suffers of mental problems ${ }^{7}$, people who are at risk and in severe emotional state, in crisis or close to it, in order to include them in the care program; secondly, acknowledge this suffering in the patient's home, show that the ASC is there to help and care about the person, to clarify issues about the illness to family members, by visiting the house and avoiding non-therapeutic interventions, such as done by the police; thirdly, know when to send the patient for special care in the region, such as to a Center for Psychosocial Care (CAPS), avoiding send patients to the network of Asylums in the State Capital. Incorrect perceptions of life crisis, and the presence of stressful factors without the appropriate social support can lead to the poor functioning of society, which may or may not lead to mental illness.

Many inappropriate solutions to the problem derive from a lack of understanding, a poor perception of correct control over one's own life, or from strategies of conflict and of low selfesteem. Capabilities of individuals and groups must be raised, which means improving problem resolutions skills, interpersonal skills, stress tolerance, motivation, hope, selfesteem, and power ${ }^{8}$. Recently an experience in Laranjal do Jari, in the heart of the Amazon forest, with 50 females who were carers of the Forest, was carried out. It was a special day where mental health should be discussed. Using a life time-line as work methodology, a "woman's head" had been created. First individually, then collectively and finally politically. These 50 women had more than 360 children, and so were very fertile. The largest risks to mental health were in the areas of child labor, denial of access to school, loss of mother at childbirth, separation from the family for the purposes of survival. Male domination by the father, step father or brother-in-law, sexual 
abuse and physical violence, the consumption of alcohol as a clear cause of violence on the wife, premature birth, and the lack of information about contraceptives. How propose a policy to create social support for these risk situations were discussed 9 . Proposals included: raising the number of places at schools (Programs like "Sementinha" - Little Seed - and "Ser Criança"Been (hild); scholarships for schools; the creation of a group of mothers to support babies who lost their mothers; groups of educators about contraceptive methods; a center to discuss issues involving female reproduction; a supply of herbs and teas (to facilitate the development of a culture of using medicine); A.A. groups. A therapeutic program, in which nothing from CID-10 or DSM IV had been used, was created ${ }^{10}$. For better or worse, the country side in Brazil is not at the same

\section{References}

1. Delgado PG. O SUS e a Lei 10216: reforma psiquiátrica e inclusão social. In: Loyola C, Macedo PRA, organizadores. Saúde mental e qualidade de vida. Rio de Janeiro (RJ): CUCA/IPUB; 2001.

2. Saramago J. Cadernos de Lanzarote. Rio de Janeiro (RJ): Companhia das Letras; 1995.

3. Loyola C. Viver a vida: identidade cultural, contexto social e qualidade de vida no estado do Maranhão. In: Loyola C, Macedo PRA, organizadores. Saúde mental e qualidade de vida. Rio de Janeiro (RJ): CUCA/IPUB; 2002.

4. Souza MF. Agentes comunitários de saúde: choque de povo. São Paulo (SP): Hucitec; 2001.

5. Rocha T. A rede em roda. In: Prefeitura Municipal de Belo Horizonte. Associação Municipal de Educadores Populares. Projeto Tudo Haver. Belo Horizonte (MG)); 2000.

6. Figueiredo AC, Cavalcanti MTM, organizadoras. A reforma psiquiátrica e os desafios da desinstitucionalização. Rio de Janeiro (RJ): CUCA/ IPUB; 2001.

7. Silva MCF, Furegato ARF, Costa Junior ML. Depressão: pontos de vista e conhecimento de enfermeiros da rede básica de saúde. Rev Latino-Am Enfermagem 2003 jan/fev; 11(1): 7-13.

8. Friedrich DBC, Sena RR. Um novo olhar sobre o cuidado no trabalho da enfermeira em unidades básicas de saúde em Juiz de Fora-MG. Rev Latino-Am Enfermagem 2002 nov/dez; 10(6): 772-79. level as what Psychiatry has produced in hospitals in these last years. There is other method taking place there and other strategies against this crisis. We want every human being to be healthy, educated, free and happy, and to have in themselves readiness to care and to be cared for. Work with Community Health Agents in Family Health Program is to agree that mental health care is a task that has to begin, and end at the community. It is over there that we will find in the daily life, challenge, problem and solution. For us as example, the words of the great Brazilian psychoanalyst Costa ${ }^{11}$ :

It is up to us, to produce the necessary enjoyment for revolutionary passion, capable of giving back to other human being, his moral dignity.

9. Loyola C, Rocha T. Fazendo história. In: Loyola C, Rocha T, organizadores. 0 caminho das pérolas: novas formas de cuidar em saúde. São Luís (MA): UNIGRAF; 2002.

10. Loyola C, Oliveira RMP. Devagar que temos pressa: a enfermagem e o campo da saúde mental. In: Venâncio AT, Cavalcanti MT, organizadoras. Saúde mental: campo, saberes e discursos. Rio de Janeiro (RJ): CUCA/IPUB; 2001.

11. Costa J. Sem fraude nem favor. Rio de Janeiro (RJ): Rocco; 1998.

\section{About the authors}

\section{Cristina Loyola}

Coordinator of the Living Life Program in the Maranhão State, 2001-2002. Head Professor of the Anna Nery School of Nursing/ UFRJ. CNPq researcher.

\section{Sebastião Rocha}

Partner in the Living Life Program in the Maranhão State, 20012002. Anthropologist and Popular Educator. President of the Popular Culture and Development Center. 